\title{
EFFECT OF AFRICAN BASIL (OCIMUM GRATISSIMUM) EXTRACTS AGAINST WATER MOULD (PYTHIUM APHANIDERMATUM) IN COWPEA
}

EMERIBE, E. O.

Department of Crop Science \& Biotechnology, Imo State University. P. M. B. 2000, Owerri, Imo

State Nigeria

E-mail: rightagrochem1@gmail.com

\begin{abstract}
The experiment was designed to investigate the effects of Ocimum gratissimum extracts in the control of Pythium aphanidermatum in cowpea. This was conducted in Crop Science and Biotechnology laboratory, Imo State University, Owerri between May to August 2018 using completely randomized design (C.R.D). There were 8 treatments replicated 4 times. Powder and Liquid extracts of the leaves of Ocimum gratissimum were applied at different concentrations $(0$, $5,10,15) \mathrm{g}$ and $(0,5,10,15) \mathrm{mls}$ respectively, inoculated on the media, Potato Dextrose Agar (PDA) in petri dishes to check the incidence and spread of the disease. Extracts of Ocimum gratissimum were effective against Pythium aphanidermatum in all the parameters tested. On inoculation of PDA media, different forms of Pythium aphanidermatum (ring or circular and dotted) in all treatments were observed, except the control. Quantitative analyses and Infrared spectroscopy of Ocimum gratissimum leaf extracts revealed the presence of active phytochemicals (alkaloids 3.6, tannins 15.4, flavonoids, oxalate 5.8, saponins 3.1) ug/g and infrared compounds (alkenes (3201.2), alcohol (3344.5), carboxylic acid (2995.5), aldehyde (2719.5), and isocyanate (2804.4) absorbed at different wave lengths in $\mathrm{cm}^{-}{ }^{1}$ were identified. Different fungal growths were cleared using different levels of extracts, $(15>10>5>0) \mathrm{mls}$ than powder extracts respectively. The ability of the extracts to exert fungicidal effects was due to the presence of active phytochemicals and infrared compounds present in the extracts.
\end{abstract}

Key words: Active Phytochemicals, Potato Dextrose Agar, Ocimum gratissimum, Pythium aphanidermatum, Bioactives

\section{https://dx.doi.org/10.4314/jafs.v19i2.3}

\section{INTRODUCTION}

Cowpea (Vigna unguiculata L. Walp) is an annual legume, commonly referred to as southern pea, black pea, crowder, labia, niebe, coupe or frijole (Amadioha, 2001, Hall et al., 2003, Onuh et al., 2005). Cowpeas are leguminous seeds that are widely produced in Africa under marginal production system (Oparaeke et al., 2005; Oparaeke, 2006; Phad, 2004). It performs well even when produced in marginal soils due to their ability to fix substantial nitrogen in the soil. (William, 2000; Hall et al., 2003; Singh and Rachie, 2006). Therefore, wider utilization of cowpea in the diet, present a source of protein that is within the means of most rural households of
Nigeria, where protein-energy malnutrition remains a serious public health concern with a $49 \%$ prevalence of stunting among children under- five years of age. Inadequate intake of protein in the diet is one of the factors that contribute to such high prevalence malnutrition in developing countries (Onuh et al., 2005).

The protein in cowpea seed is rich in amino acid, lysine and tryptophan, compared to cereal grains; however, it is deficient in methionine and cysteine when compared to animal protein. Therefore, cowpea seed is valued as a nutritional supplement to cereals and an extender of animal protein (Phad, 2004). Cowpea can be used at all stages of

Journal of the Faculty of Agriculture and Veterinary Medicine, Imo State University Owerri website: www ajol.info 
growth as a vegetable crop. The tender green leaves are an important food source in Africa and are prepared as a pot herb, like spinach. Immature snapped pods are used in the same way as snap beans often being mixed with other foods. Green cowpea seed are boiled as a fresh vegetable, of maybe canned or frozen.

In spite of its nutritional and agronomical importance, cowpea yield is low due to pest and many diseases including damping off and stem rot. The disease was reported in USA, Brazil, Tanzania, Nigeria and South Africa (Aveling and Adandonon, 2000). In Nigeria, the diseases reported were caused by a complex of fungi including species of Pythium, Phytophthora, Colletotricum and Scleretium (Singh and Rachie, 2006). Cowpeas are susceptible to a wide range of pest and pathogens that attacks the crop at all stages; rust caused by Uromyces appendiculstum (Onuh et al., 2005), soft stem and root rot caused by Pythium aphanidermatum (Dutta, 2005; Gale, 2002). The most common found on beans, especially cowpea are Pythium ultimum, $P$. debaryanum, $P$. mytiotylum, $P$. heli-coids, $P$. rostratum, $P$. oligandium, P. aphanidermatum, (Dutta, 2005). Pythium is a soil pathogenic fungus belonging to the family Pythiaceae, it usually attack seedlings at the base and root under condition of overcrowding and over watering (Dutta, 2005).

Since the end of the Second World War, there has been a great boom in the use of fungicides throughout the world (William, 2000). In the early 60's following the dangerous consequences to man and environment in the area of phytotoxicity, there is an urgent need for alternative method of plant disease control. This scenario necessitates the search for the development of ecological, sustainable fungi- control method which are effective to the target species and creates minimal adversity for non-target species.
Historical success have been recorded in the use of Neem (Azadirachtin) and similar alkaloids, flavonoids, terpeniods from Aloe (Aloe vera), Ginger (Zingiber officinale R.) and Bitter kola (Gracinia cola) as biopesticides and fungicides. According to Oparaeke et al., (2005) Aloe contains some active ingredients that are fungicidal at various concentrations, they possess fungicidal activity against the mycelia growth and Sclerotial germination of soil fungus. In the past two decades research were directed at developing new bio-pesticides that were efficacious against pest but present minimal hazards to the user and damage to the environment (Oparaeke et al., 2005). Oparaeke, (2006) indicated that bio pesticides could offer such a management options. Dialoke et al., 2014, have successfully controlled a pod sucking bug, Riptortus dentipes fab. on short duration pigeon pea in Owerri, by spraying 12.51/ha of formulated Neem seed oil for four weeks interval.

Ocimum gratissimum (Africa Basil) belongs to the family lamiaceae. It is cultivated in many gardens around village huts in Nigeria for its medical and culinary uses. It is believed to have originated in Central Africa and South Asia (Okpala, 2015). Phytochemical screening of this plant has revealed the presence of many active ingredients such as flavonoids, triterpenens, alkaloids, citrasapoins, eugenol, linaol, methyl cinnamate camphor and thymol (Singh, 1994, Okpala, 2015). Eugenol, an isolate form of $O$. gratissimum has been observed to possess anti-helminthic nematicidal and insecticidal properties, several species and varieties of the genus ocimum have been reported to yield oils of diverse nature; which are commonly called basilica oils. Researches showed that the Ocimum gratissimum extracts exhibited antifungal activities on all fungi tested. (Okpala, 2015) 
Volume 19, Number 2, October 2021, pp 23 - 29

Due to identifiable problems (chemical residues, biodegradation, phytotoxicity, pollution) associated with chemical control strategies, alternative control methods are being sought. Strategies that would provide useful information on cheaper, affordable, natural and environmentally friendly insecticide in the control of rot disease in Vigna unguiclata (L.) Walp.

Hence this study was designed to screen the extracts of Ocimum gratissimum leaves in the control of water mould, Pythium aphanidermatum in inoculated Potato Dextrose Agar media in petri dishes.

\section{MATERIALS AND METHODS}

This experiment was conducted in June 2018, at the Crop Science and Biotechnology laboratory of Imo State University Owerri, Nigeria. Four cowpea-affected lower leaves were harvested from growing cowpea seedlings, crushed and used to inoculate the Potato Dextrose Agar media, using wire loop. The leaves were dried and ground for powder extract. $100 \mathrm{~g}$ of the powder extract was mixed with $500 \mathrm{mls}$ of distilled water and the solution was left to soak for an hour and then sieved with a clean white cloth, this yielded $400 \mathrm{ml}$ of the crude liquid extract. Powdered extracts were measured. 8 treatment levels $(0$, $5,10,15) \mathrm{ml}$ and $(0,5,10,15) \mathrm{g}$ were used respectively. These were replicated four times, giving 32 experimental units, using completely randomized design. The Potato Dextrose Agar under aseptic condition was locally prepared with Irish potato bought from Owerri market, Imo State Nigeria, washed, peeled, boiled till it formed mesh in the pot; smeared with a wooden spatula to avoid lumps in the medium. The gelatinous paste was allowed to cool. $5 \mathrm{~g}$ of agar-agar measured, was mixed with the prepared potato dextrose. Potato Dextrose Agar was poured into 32 petri-dishes and kept to solidify. Streptomycin powder dissolved in distilled water at $1 \mathrm{ml}$ each was injected into petri-dishes except the control. This was done with syringe to inhibit the growth of bacteria and fungi present in the medium excluding $P$. aphanidermatum. The inoculum was streaked on it with the aid of sterilized wire loop. The medium was left to incubate for 72 hours at $37^{\circ} \mathrm{C}$, inspected every 24 hours with hand lens to identify Pythium aphanidermatum. After 72 hours incubation, the extracts were injected into the medium according to treatments, without the control. The medium was re-incubated again for 24 hours at $37^{\circ} \mathrm{C}$. Data collection were based on morphology, (round or circular, ring or dotted forms), colour/appearance, (curtney brown).

\section{RESULTS AND DISCUSSION}

The Phytochemical screening of the plant extracts revealed the presence of (alkaloids, tannins, flavonoids, saponin, oxalate) $\mathrm{ug} / \mathrm{g}$ (Onuh et al., 2005, Dialoke et al., 2014) Infrared spectroscopy of the extracts revealed some bioactive compounds like aldehyde, carboxylic acid, isocyanate, alkenes, alcohol, absorbed at different wave lengths (Oparaeke et al., 2006, Dialoke et al., 2014). The experiment showed that different concentrations of extracts of Ocimum gratissimum inhibited the radial growth, changes in colour and appearance of the media from curtney brown to white at different time-intervals, very pronounced in liquid extracts than powder extracts. This is an indication that the extracts had effects on Pythium aphandermatum. (Amadioha, 2001 and Al- Abed et al., 1993, Onuh et al., 2005). Therefore, metabolites contained in the extracts exerted varied fungicidal actions on the incitant organism as opined by (Onuh $e t$ al., 2005 and Amadioha, 1998) that aqueous solution of Jatropha curcas controlled Pythium aphanidermatum while Azadirachta indica and Xylopia aethiopica were fungicidal on Colletotricum lindemuthianum in cowpea.

\section{Journal of the Faculty of Agriculture and Veterinary Medicine, Imo State University Owerri website: www ajol.info}




\section{CONCLUSION}

There are a good number of methods for managing plant diseases, therefore disease control is a continual battle since new challenges keep surfacing. The role of plants as sources of fungitoxic chemicals and their importance in the control of different plant pathogens are many and varied. Synthetic pesticides are costly and difficult to obtain. Worries on their safety are issues in developed and under-developed countries. Therefore, botanicals are cheap, easy to formulate, readily available and eco-friendly, hence, the use of Ocimum gratissimum in the control of Pythium aphandermatum in cowpea.

\section{RECOMMENDATION}

Further studies on Ocimum gratissium should be carried out through HPLC, High Pressure Liquid Chromatography, Nuclear Molecular Resounance NMR and GCMS, Gas Chromatography, Mass Spectrometer to determine the active principles causing the pathological effects and their structure.

Journal of the Faculty of Agriculture and Veterinary Medicine, Imo State University Owerri website: www ajol.info 


\section{REFERENCES}

Al-Abed, A.S, Qasem, J.R and Abu-Blam. (1993). Anti-fungal effects of some common wild plant species on certain plant pathogenic fungi. Dirasat. Pure and Applied Science, 20: 149-158.

Amadioha, A. C. (1998). Fungitoxic activity of extracts of Azadirachta indica and Xylopia Aethiopica on Coelletotrichum lindemuthianum in cowpea. Journal of Herbs, Spices and Medicinal Plants, 6: 33-40. doi.org/10.1300/J044v06n02_04

Amadioha, A. C. (2001). Fungitoxic effects of extracts of Azadirachta indica against Cochliobolus miyabeanus causing brown spot disease of rice. Archives of Phytopathology and Plant Protection, 35(1), 37-

42.

\section{doi.org/10.1080/0323540021000009597}

Aveling, T. A. S. and Adandonon, A. (2000). Pre- and post-emergence damping-off ofCowpea caused by Pythiumultimum in South Africa. Plant Disease 84 (8): 922. doi.org/10.1094/PDIS.2000.84.8.922B

Dialoke, S.A., Emosairue, S.O., Egho and Ogoke, I.J. (2014). Insect species associated with early maturity pigeon pea in Nigeria. Indian Journal of Entomology, 76(4):330336.

Dutta, A.C. (2005). Botany for Degree Students, Oxford University Press New York, pp. 410-412.

Gale, A.B. (2002). A Simplified Technique for Recovery Pythium from Infested Plant Tissue, In Suleiman, M.N. and Emua, S.A. (2009) Efficacy of four plant extracts in the control of root rot disease of cowpea (Vigna unguiculata [L.] Walp). African Journal of Biotechnology, 8 (16), 3806-3808.

Hall E.A, Cisse N, Thiaw S, Elawad HOA, Ehlers JD, Ismal A.M, Fery R.L, Roberts P.A, Kitch L.W, Murdock, L.L, Boukar .O, Philips R.D, M.C Watters K.H. (2003). Development of cowpea cultivars and germplasm by Bean/Cowpea CRSP. Field
Crop Research, 82b, 103-134. doi.org/10.1016/S0378-4290(03)00033-9

Okpala, B. (2015). Phytochemical and antimicrobial effects of extracts of some local herbs on selected pathogenic organism. Flavour fragrance Journal 13:107-114.

Onuh M.O, Ohazurike, N.C, Emeribe, E.O. (2005). Efficacy of Jatropha curcas leaf extract in the control of brown blotch disease of cowpea, Vigna Unguiculata ( L. Whalp). Journal of Plant Protection, 22: 46-52.

Oparaeke, A.M. (2006). Field Screening of Nine Plants Extract for the Control of Post Flowering Insect Pest of Cowpea (Vigna unguiculata (L.) Walp). Archives of Phytopathology and Plant Protection, 3(39): 225-230. doi.org/10.1080/03235400500094399.

Oparaeke, A.M; Dike M.C, and Amatobi.C.I. (2005). Effect of Application of Different Concentrations and Appropriate Schedules of Aqueous Garlic (Allium sativum L.) bulb extract against (Tavigravllatomentosicollis) on cowpea Vigna unguiculata (L.) Walp. Archives of Phytopathology and Plant Protection, 38: 1-6.

Phad, B.O. (2004). Determination of the chemical composition of the cowpea (Vigna unguiculata (L.) Walp). Journal of Agriculture and Food Chemistry 18: 567-579

Singh, D. (1994). Scope of medicinal and aromatic plants in pest management. International symposium on Allelopathy in sustainable Agriculture, forestry and environment, p. 68. New Delhi, sept. 6-8.

Singh, S. R. and Rachie, K. O. (2006). Cowpea Research, Production and Utilization. International Institute of Tropical Agriculture (IITA). John Wiley and Son, Chichester, Great Britain.

William, R. J. (2000). Disease of cowpea Vigna unguiculata (L.) Walp in Nigeria PANS, 21: 253- 267. doi.org/10.1080/09670877509411407 


\section{APPENDIX}

FTIR-SPECTROSCOPY Ocimum gratissimum .L AND THE DIFFERENT WAVE LENGTHS AT WHICH THE DIFFERENT ORGANIC COMPOUNDS WERE ABSORBED Table showing FTIR - Spectrum from

\begin{tabular}{|c|c|c|c|c|c|}
\hline & \multicolumn{2}{|c|}{ RAW SAMPLE } & \multicolumn{3}{|c|}{ WATER EXTRACT } \\
\hline $\begin{array}{l}\text { Wave } \\
\text { number } \\
\left(\mathrm{cm}^{-1}\right)\end{array}$ & Functional group & Remarks & $\begin{array}{l}\text { Wave number } \\
\left(\mathrm{cm}^{-1}\right)\end{array}$ & Functional group & Remarks \\
\hline 758.705 & Alkyl halides $\mathrm{C}-\mathrm{Cl}$ & Stretching & 754.5508 & Alkanes C-H & $\begin{array}{l}\text { Out-of-plane, } \\
\text { bend }\end{array}$ \\
\hline 886.544 & Vinylidene, C-H & $\begin{array}{l}\text { Out-of-plane, } \\
\text { bend }\end{array}$ & 846.9621 & Vinyl C-H & $\begin{array}{l}\text { Out of plane, } \\
\text { bend }\end{array}$ \\
\hline 1203.493 & $\begin{array}{ll}\text { Aromatic } & \text { secondary } \\
\text { amine } \mathrm{CN} & \end{array}$ & Stretching & 1191.94 & Phosphine oxide & Stretching \\
\hline 1403.363 & Primary amine $\mathrm{NH}$ & Bend & 1284.99 & Aromatic amine & Stretching \\
\hline 1472.363 & Primary amine $\mathrm{NH}$ & Stretching & 1416.227 & Primary amine NH & Bend \\
\hline 1619.513 & Acid halide, $\mathrm{C}=\mathrm{O}$ & Stretching & 1618.015 & Acid halide, $C=0$ & Stretching \\
\hline 1853.414 & $\begin{array}{l}\text { Open-chain acid } \\
\text { anhydrides }\end{array}$ & Stretching & 1852.189 & Alkane,C-H & Stretching \\
\hline 1989.118 & Alkene, $\mathrm{C}=\mathrm{C}$ & Stretching & 1960.972 & Alkyne & Stretching \\
\hline 2078.369 & Alkyne, & Stretching & 2088.369 & Thiols S-H & Stretching \\
\hline 2198.118 & Aromatic $\mathrm{C}-\mathrm{H}$ & Stretching & 2249.232 & Aldehyde, C-H & Stretching \\
\hline 2264.409 & Thiols, S-H & Stretching & 2473.808 & Acid anhydrides & Stretching \\
\hline 2462.647 & Aldehyde, C-H & Stretching & 2605.374 & Alkane, C-H & Stretching \\
\hline 2624.879 & Aldehyde C-H & Stretching & 2719.582 & Alcohol, OH & Broad \\
\hline 2762.0543 & Isocyanate $\mathrm{N}=\mathrm{C}=\mathrm{O}$ & Stretching & 2804.422 & Alkyne & Sharp \\
\hline 2894.404 & Carboxylic acid & Stretching & 2995.572 & Primary amine NH & Stretching \\
\hline 2977.921 & Alkene, C-H & Stretching & 3076.572 & Alcohol, $\mathrm{OH}$ & Stretching \\
\hline 3236.291 & Alkene C-H & Stretching & 3201.259 & Alcohol, OH & Stretching \\
\hline 3338.875 & Alcohol OH & Stretching & 3344.517 & Alcohol & Sharp \\
\hline 3540.413 & Alcohol OH & $\begin{array}{l}\text { Broad, } \\
\text { Stretching }\end{array}$ & 3570.316 & Alcohol, $\mathrm{OH}$ & Stretching \\
\hline 3669.346 & Alcohol OH & Stretching & 3681.453 & Alcohol, OH & $\begin{array}{l}\text { Broad, } \\
\text { stretching }\end{array}$ \\
\hline 3791.549 & Alcohol OH & Stretching & 3825.429 & $\begin{array}{l}\text { Carboxylic acid, } \\
\mathrm{OH}\end{array}$ & Stretching \\
\hline
\end{tabular}

Journal of the Faculty of Agriculture and Veterinary Medicine, Imo State University Owerri website: www ajol.info 
Journal of Agriculture and Food Sciences Emeribe E. O.

Volume 19, Number 2, October 2021, pp 23 - 29.

PYTOCHEMICAL ANALYSES AND THEIR PERCENTAGE (\%) COMPOSITIONS IN Ocimum gratissimum leaves

\begin{tabular}{cll}
\hline S/No & Phytoconstituents & Concentration Ug/G \\
\hline $\mathbf{1}$ & Alkaloids & 3.6 \\
$\mathbf{2}$ & Sapogenin & 11.63 \\
$\mathbf{3}$ & Quinine & 11.09 \\
$\mathbf{4}$ & Protein & 3.1 \\
$\mathbf{5}$ & Tannins & 15.43 \\
$\mathbf{6}$ & Catechin & 6.29 \\
$\mathbf{7}$ & Flavonoids & 7.68 \\
$\mathbf{8}$ & Lunamarin & 2.63 \\
$\mathbf{9}$ & Oxalate & 5.88 \\
$\mathbf{1 0}$ & Saponins & 3.14 \\
$\mathbf{1 1}$ & Anthocyanin & 4.14 \\
\hline
\end{tabular}

Journal of the Faculty of Agriculture and Veterinary Medicine, Imo State University Owerri website: www ajol.info 